\title{
CENY SUROWCÓW ENERGETYCZNYCH A CENY PRODUKTÓW ROLNO-ŻYWNOŚCIOWYCH - BEZPIECZEŃSTWO ENERGETYCZNE A BEZPIECZEŃSTWO ŻYWNOŚCIOWE
}

\begin{abstract}
Ostatnie lata charakteryzują się znaczącym wzrostem poziomu cen surowców rolnych i żywności, czemu towarzyszy ich podwyższona zmienność. Za przyczynę takiego stanu rzeczy często wskazuje się wzrost powiązań rynków rolnych z rynkiem energii. Dzieje się tak w wyniku coraz powszechniejszego wykorzystywania surowców rolnych do produkcji energii odnawialnej, co uzasadnia się między innymi kwestiami środowiskowymi oraz bezpieczeństwem energetycznym.

W tym kontekście pierwszym celem badań była ocena powiązań między cenami surowców energetycznych a cenami surowców rolnych i żywności. Na tym tle podjęto próbę oceny zależności między bezpieczeństwem energetycznym a bezpieczeństwem żywnościowym. W badaniach skoncentrowano się na perspektywie globalnej.

W badaniach potwierdzono wzrost powiązań między cenami nośników energii a cenami surowców rolnych i żywności. Wyraża się to między innymi poprzez wzrost korelacji między indeksem cen surowców rolnych a cenami ropy Brent, jak również widocznym skorelowaniem ich zmienności. Wzrost powiązań cenowych wynikał z wielu przyczyn, w tym $z$ aktywnej polityki państw rozwiniętych promującej produkcję i zużycie biopaliw.

Efektem wzrostu cen żywności było obniżenie bezpieczeństwa żywnościowego, głównie w krajach rozwijających się, czemu towarzyszyły niepokoje społeczne. Równocześnie w krajach będących producentami biopaliw nastąpiła poprawa bezpieczeństwa energetycznego. Wydaje się jednak, że wraz z odbudową stanu zapasów żywności, obniżeniem cen ropy oraz stabilizacją zaangażowania sektora rolnego negatywne konsekwencje dla bezpieczeństwa żywnościowego będą coraz słabsze.

Słowa kluczowe: ceny rolno-żywnościowe, ceny energii, bezpieczeństwo energetyczne, bezpieczeństwo żywnościowe.
\end{abstract}

\section{WSTEP}

Ostatnia dekada charakteryzuje się znaczącym wzrostem poziomów cen rolnożywnościowych oraz podwyższoną zmiennością tych cen. Powszechnie mówi się, że mamy do czynienia z głęboką zmianą strukturalną, która kończy okres wieloletniego spadku realnych cen rolno-żywnościowych. Kwestia ta stała się przedmiotem rosnącego zainteresowania opinii publicznej na całym świecie ze względu na jej ewentualny wpływ zarówno na sytuację producentów, jak i konsumentów żywności.

Równocześnie przeprowadzono setki badań naukowych oraz analiz mających na celu identyfikację przyczyn, mechanizmów i konsekwencji destabilizacji rynków rolnożywnościowych. Zgodnie $\mathrm{z}$ prezentowanymi $\mathrm{w}$ literaturze poglądami wśród

\footnotetext{
${ }^{1}$ Dr inż. Mariusz Hamulczuk, Wydział Nauk Ekonomicznych, Szkoła Główna Gospodarstwa Wiejskiego, ul. Nowoursynowska 166,02-787 Warszawa, e-mail: mariusz_hamulczuk@sggw.pl
} 
najważniejszych przyczyn leżących u podstaw takiego przebiegu cen wskazuje się między innymi wzrost popytu na żywność, pojawiające się okresowo negatywne konsekwencje zmian klimatycznych, finansyzację rynków surowcowych i związane $\mathrm{z}$ nią działania $\mathrm{o}$ charakterze spekulacyjnym oraz coraz silniejsze powiązanie cen rolnych $\mathrm{z}$ cenami surowców energetycznych. Ta ostatnia przyczyna jest przywoływana przez niektórych autorów ${ }^{2}$ jako najważniejsza w ciągu wzajemnie ze sobą powiązanych przyczyn, które w literaturze anglojęzycznej określa się jako perfect storm.

Obserwowane zmiany cen żywności znajdują odzwierciedlenie w ograniczaniu możliwości zabezpieczenia podstawowych potrzeb żywnościowych ludności. Jest to szczególnie odczuwalne w wypadku ubogich osób i niezamożnych społeczności. W związku z tym pojawiają się pytania dotyczące sensu, skali czy formy zaangażowania sektora rolnego w produkcję energii odnawialnej. W tym kontekście celem niniejszej pracy jest ukazanie zmian cen rolno-żywnościowych w czasie, wskazanie przyczyn leżących u podstaw ich zmian oraz naświetlenie wzajemnych powiązań i zależności między nimi a cenami surowców energetycznych. W analizie istotną rolę odgrywają ceny ropy, która ma największy udział w światowym indeksie cen energii. Na tym tle podjęto próbę skonfrontowania kwestii bezpieczeństwa żywnościowego $\mathrm{z}$ bezpieczeństwem energetycznym w zarówno ujęciu historycznym, jak i w perspektywie najbliższych lat.

\section{CENY SUROWCÓW ROLNYCH I ŻYWNOŚCI}

Między cenami surowców rolnych a cenami żywności istnieje silny związek przyczynowo-skutkowy, ponieważ koszty surowca, determinowane jego ceną, stanowią często znaczący udział wartości produktu finalnego. Siła tego związku zależy głównie od stopnia przetworzenia produktu finalnego oraz od udziału kosztów pozasurowcowych.

W tym miejscu warto zastanowić się, od czego zależą ceny surowców rolnych (rys. 1). Można uznać, że są one funkcją wielu czynników popytowych i podażowych, krajowych i globalnych, w tym oczekiwań formułowanych przez uczestników rynku. Ważną rolę w procesie formułowania oczekiwań odgrywają giełdy towarowe. Cena rynkowa w tym układzie jest ceną równoważącą popyt z podażą. Jakakolwiek zmiana któregoś ze składników podaży (na przykład plonów) lub popytu (między innymi zapotrzebowania przemysłowego na biopaliwa) powinna znaleźć odzwierciedlenie w cenie rynkowej. Jednak ze względu na niepełną informację uczestników rynku oraz niepewność proces ten niekoniecznie musi zachodzić liniowo.

Ceny surowców rolnych są również uwarunkowane czynnikami pozasektorowymi: makroekonomicznymi, ograniczeniami technologicznymi, pogodowymi czy interwencją państwa. Dodatkowo należy pamiętać, że ceny krajowe zależą nie tylko od uwarunkowań wewnętrznych, ale również, a może przede wszystkim - od cen światowych. Cenami światowymi określa się ceny na rynkach, które z popytowego lub podażowego punktu widzenia odgrywają kluczową rolę.

\footnotetext{
${ }^{2}$ B.D. Wright, Global Biofuels: Key to the Puzzle of Grain Behavior, „Journal of Economic Perspectives" 28/1 (2014), s. 73-98.
} 
Rys. 1. Determinanty cen surowców rolnych

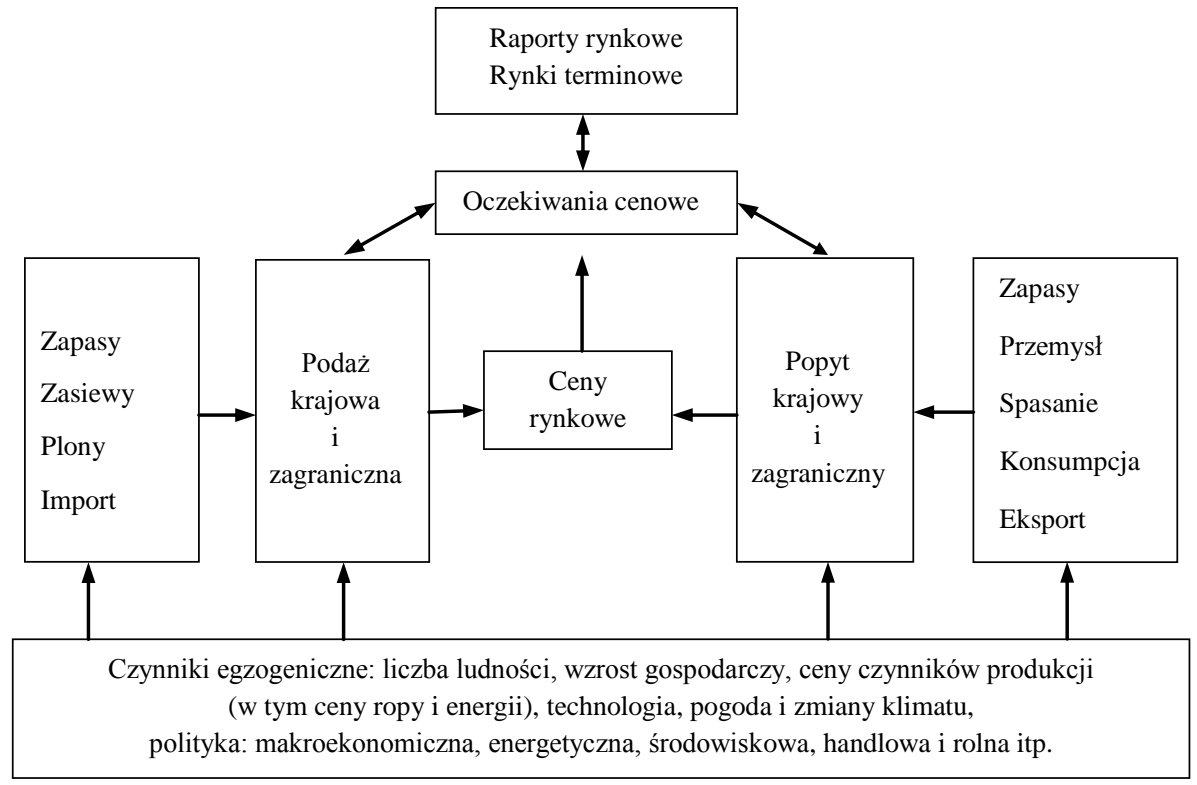

Źródło: opracowanie własne.

Wyjaśniając, dlaczego w ostatnich latach poświęcono tyle miejsca dyskusji na temat cen rolno-żywnościowych, należy wyjść od przedstawienia tendencji obrazujących kształtowanie się światowych cen surowców rolnych wykorzystywanych do produkcji żywności. Jak wynika z rysunku 2, po 2005 roku nastąpiła zasadnicza zmiana dotychczasowych prawidłowości. Ceny nominalne, pozostające w trendzie horyzontalnym od początku lat siedemdziesiątych, po 2005 roku wzrosły blisko dwukrotnie. Z kolei realne ceny surowców rolnych znajdujące się przez około 40 lat w tendencji spadkowej, przerwanym na trzy lata przez kryzys energetyczny lat siedemdziesiątych, również zmieniły swój trend na wzrostowy. Zatem zasadnicze pytania wiążą się ze wskazaniem przyczyn takiego stanu rzeczy, konsekwencji dla uczestników rynku oraz trwałości nowych trendów. 
Rys. 2. Indeksy światowych cen surowców rolnych $(2010=100$, ceny realne w USD z 2005 roku)

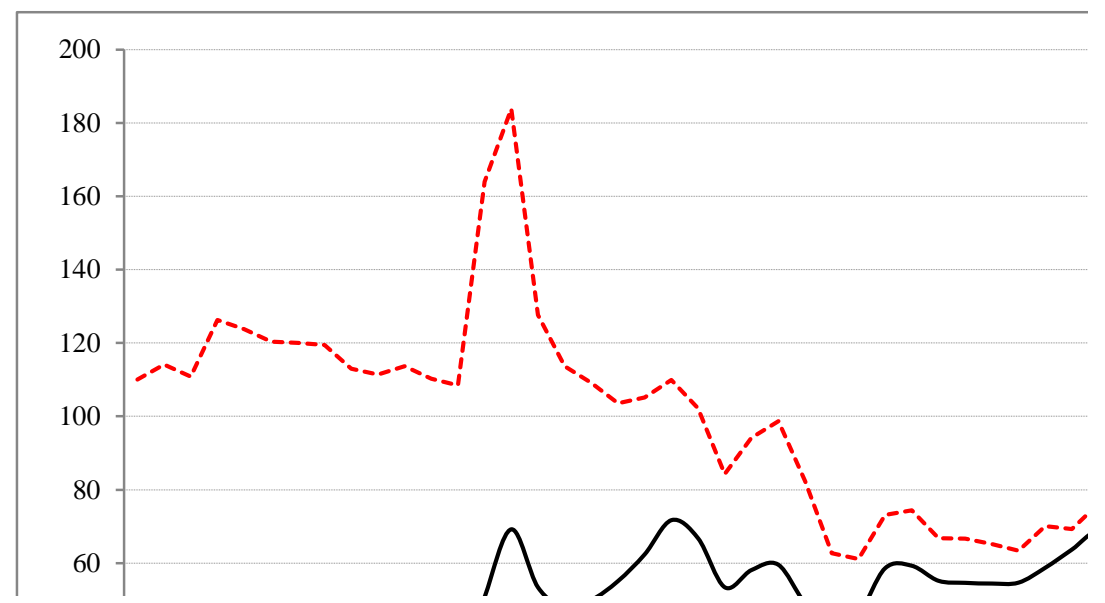

Źródło: opracowanie własne na podstawie danych Banku Światowego.

Ze względu na to, że zmiany cen surowców rolnych były dość znaczące oraz miały wiele negatywnych implikacji, przeprowadzono wiele badań i analiz mających na celu ustalanie ich przyczyn. Badania te były wielokrotnie inicjowane przez polityków i różne organizacje, często pod naciskiem opinii publicznej, w reakcji na nieprzewidywany wzrost cen i niepewność co do ich dalszego przebiegu. Bazując na literaturze, można spotkać się z różnymi poglądami co do przyczyn takiego stanu rzeczy. Wśród czynników sprawczych tych napięć najczęściej wymienia się:

- wpływ zmian klimatycznych na rolnictwo wywołujący okresowe obniżenie plonów oraz pojawiające się niedobory żywności ${ }^{3}$;

- $\quad$ wzrost światowego popytu na skutek zmian społeczno-demograficznych w krajach rozwijających się ${ }^{4}$;

- $\quad$ niskie stopy procentowe oraz wahania kursów walut mające wpływ na krajowe ceny produktów ${ }^{5}$;

- działania spekulacyjne związane $\mathrm{z}$ zaangażowaniem inwestorów finansowych na rynkach towarowych ${ }^{6}$;

\footnotetext{
${ }^{3}$ R. Trostle, Global Agricultural Supply and Demand: Factors Contributing to the Recent Increase in Food Commodity Prices, USDA, Outlook Report WRS-0801, 2008; B. Troester, The determinants of the recent food price surges - a basic supply and demand model, „Berlin Working Papers on Money, Finance, Trade and Development" 2012/6.

${ }^{4}$ D. Headey, S. Fan, How Did It Happen? How Has It Hurt? and How Can We Prevent the Next One?, „Research Monographs” 2010/165, IFPRI .

${ }^{5}$ J. Baffes, A. Dennis, Long-term drivers of food prices, „Policy Research Working Paper, World Bank, Washington, D.C" 2013/6455; S. Nazlioglu, U. Soytas, Oil price, agricultural commodity prices and the dollar: A panel cointegration and causality analysis, „Energy Economics” 2012/34, s. 1098-1104.

${ }^{6}$ M. Robles, M. Torero, J. von Braun, When speculation matters, „Issue Brief” 2009/57, Washington, DC, IFPRI; I-W. Cheng, W. Xiong, The Financialization of Commodity Markets, „NBR Working Paper” 2013/19642; M.G. Will, S. Prehn, I. Pies, T. Glauben, Is financial
} 
- $\quad$ krótkowzroczne, publiczne polityki rolne w odpowiedzi na wzrost cen żywności (protekcjonizm, restrykcje handlowe itd.) ${ }^{7}$;

- $\quad$ coraz silniejsze powiązanie cen surowców rolnych z cenami energii (zarówno przez stronę popytową, jak i podażową) ${ }^{8}$.

Ze względu na kompleksowość zmian czynników warunkujących kształtowanie się popytu i podaży identyfikacja przyczyn rosnącej zmienności cenowej surowców rolnych nie jest łatwa. Wielu autorów ${ }^{9}$ wskazuje, że mamy do czynienia z kombinacją wielu tych czynników jednocześnie lub też z ich następowaniem po sobie. Ogólnie podkreśla się, że w pierwszej kolejności do wzrostu cen żywności i surowców rolnych przyczynił się wzrost popytu w krajach rozwijających się. Jednakże nie doprowadziło to do znaczącego wzrostu cen na rynku rolno-żywnościowym. Dopiero regulacje w zakresie polityki biopaliw wprowadzane w krajach rozwiniętych oraz towarzyszący temu wzrost zużycia przemysłowego przyczyniły się do zmniejszenia stanu zapasów na rynku surowców rolnych. Równocześnie doszło do deprecjacji dolara amerykańskiego, co samo w sobie przełożyło się na wyższe ceny światowe wszystkich surowców, nie tylko rolnych. Oczekiwania co do wzrostu cen oraz wysoka ich zmienność spowodowały wzrost zainteresowania rynkami surowcowymi przez instytucje finansowe oraz przez spekulantów. Wysoka niepewność, jaka towarzyszyła rynkom rolnym, prowadziła do wzrostu polityki protekcjonistycznej. Pojawiające się jedna za drugą zapowiedzi ograniczeń eksportowych doprowadziły do paniki, której apogeum przypadło na pierwszą połowę 2008 roku. Globalna recesja oraz wzrost produkcji doprowadziły do silnej przeceny na rynku surowcowym na przełomie lat 2008/2009. Jednak już w roku 2010 wiele $\mathrm{z}$ wymienionych czynników, a w szczególności niesprzyjające warunki pogodowe oraz wzrosty cen ropy, dało znać o sobie, co doprowadziło do ponownego wzrostu cen surowców rolnych ${ }^{10}$.

\section{CENY SUROWCÓW ROLNYCH A CENY ENERGII}

W niniejszym rozdziale dokonano próby wskazania kanałów potencjalnych współzależności cen surowców rolnych $\mathrm{z}$ cenami energii oraz określono stopień powiązania między tymi cenami. Za podstawę teoretycznych rozważań posłużył schemat zawarty na rysunku 1. Wychodząc od strony podażowej można stwierdzić, że dla producentów rolnych ceny energii, a w szczególności ceny paliw, mają znaczenie kosztotwórcze. Wzrost cen nośników energii znajduje przełożenie w wyższych kosztach

speculation with agricultural commodities harmful or helpful? A literature review of current empirical research, „Diskussionspapier“ 2012/26 des Lehrstuhls für Wirtschaftsethik an der MartinLuther-Universität Halle-Wittenberg, Halle.

${ }^{7}$ R. Sharma, Food Export Restrictions: Review of the 2007-2010 Experience and Considerations for Disciplining Restrictive Measures, „FAO Commodity and Trade Policy Research Working Paper" 2011/32.

${ }^{8}$ H. de Gorter, D. Drabik, D.R. Just, Biofuel Policies and Food Grain Commodity Prices 2006 2012: All Boom and No Bust?, „AgBioForum” 16/1-13 (2013); M. von Lampe, A. Kavallari, H. Bartelings, H. v. Meijl, M. Banse, J. Ilicic-Komorowska, F. Junker, F. van Tongeren, Fertiliser and Biofuel Policies in the Global Agricultural Supply Chain: Implications for Agricultural Markets and Farm Incomes, „OECD Food, Agriculture and Fisheries Papers”2014/69.

${ }^{9}$ D. Headey S. Fan, op. cit.

${ }^{10}$ R. Trostle, D. Marti, S. Rosen, P. Westcott, Why Have Food Commodity Prices Risen Again?, WRS-1103, Economic Research Service/USDA, 2011. 
paliw, energii czy nawozów. Przekłada się to na wyższe ceny surowców rolnych, ale jednocześnie prowadzi do obniżenia opłacalność produkcji i jej spadku w kolejnych sezonach. Kanał kosztowy jest uważany za tradycyjny kanał łączący rynek rolny $\mathrm{z}$ rynkiem surowców energetycznych.

Schemat powiązań dość istotnie się zmienił wraz z rozwojem rynku biopaliw w skali globalnej po roku 2005, kiedy nastąpił znaczący wzrost produkcji biopaliw z wykorzystaniem surowców rolnych (tzw. pierwszej generacji). Według danych OECD w latach 2005-2013 produkcja bioetanolu wzrosła blisko 2,5-krotnie, biodiesla zaś około 7krotnie. Do głównych producentów oraz konsumentów biopaliw w świecie należą Brazylia, Stany Zjednoczone, kraje Unii Europejskiej oraz Kanada (generalnie państwa wysoko rozwinięte oraz kraje mające nadwyżki żywnościowe). Do produkcji biopaliw wykorzystuje się głównie kukurydzę, rzepak oraz trzcinę cukrową. Według danych OECD w latach 2008-2013 około 11\% światowej produkcji zbóż paszowych (głównie kukurydzy), 11\% olejów roślinnych oraz blisko 17\% trzciny cukrowej przeznaczono do produkcji biopaliw.

W warunkach rynkowych ekonomiczne możliwości wykorzystania surowców rolnych na biopaliwa wyznacza relacja między ceną danego surowca a ceną ropy oraz współczynniki konwersji poszczególnych surowców. Przy wysokiej relacji mamy do czynienia $\mathrm{z}$ brakiem ekonomicznych przesłanek produkcji biopaliw, i odwrotnie. Wydaje się, że bez aktywnej roli państwa wzrost popytu przemysłowego, jaki odnotowano w ostatniej dekadzie, nie byłby możliwy, ponieważ relacje cenowe nie zawsze uzasadniały takie przeznaczenie surowców rolnych. Dlatego wiele państw zaimplementowało różne rozwiązania polityczne, które miały się przyczynić do wzrostu produkcji paliw pływnych na bazie surowców odnawialnych ${ }^{11}$. Instrumenty polityki biopaliwowej sprowadzają się głównie do subsydiowania konsumpcji (dotacje, ulgi podatkowe), ustanawiania taryf importowych oraz obowiązkowych, minimalnych i maksymalnych udziałów domieszek komponentów pochodzenia organicznego w paliwach płynnych. Polityki w poszczególnych krajach i regionach mogą się różnić pod względem kombinacji i wymiaru stosowanych instrumentów, niemniej w każdym wypadku ich efektem jest sztuczne zwiększenie popytu przemysłowego na surowce rolne ${ }^{12}$.

Regulacje w zakresie polityki biopaliwowej nie tylko prowadzą do wzrostu popytu, ale również zmniejszają jego elastyczność (chodzi tutaj o wymagania dotyczące minimalnych udziałów domieszek). Popyt na biopaliwa wykazuje się wysoką sztywnością, ponieważ nie może być on obniżony poniżej minimalnych limitów domieszek oraz zwiększony powyżej poziomów wynikających z technologicznych ograniczeń silników spalinowych. Efektem tego może być duży wzrost cen i ich istotna zmienność w warunkach szoków podażowych (susza, powódź czy też wysoka nadprodukcja) ${ }^{13}$. Niepewność co do kształtu polityki oraz możliwości spełnienia wymagań ilościowych silnie oddziałują na oczekiwania cenowe oraz tworzą dodatkowe ryzyka. Przyjęcie wysokich limitów

\footnotetext{
${ }^{11}$ L.L. McPhail, B.A. Babcock, Impact of US biofuel policy on US corn and gasoline price variability, „Energy” 37/1 (2012), s. 505-513.

${ }^{12}$ M. Hamulczuk, Polityka biopaliwowa a ceny surowców rolnych - wybrane problemy, „, Roczniki Naukowe Stowarzyszenia Ekonomistów Rolnictwa i Agrobiznesu” 16/2 (2014), s. 82-87.

${ }^{13}$ W.E. Tyner, F. Taheripour, Ch. Hurt, Potential Impacts of a Partial Waiver of the Ethanol Blending Rules, Oak Brook, IL: Farm Foundation, 2012, s. 1-13.

B.D. Wright, 2014, op. cit.
} 
minimalnych udziałów w początkowej fazie wprowadzania produkcji biopaliw doprowadziło uczestników rynku do przekonania, że trudno będzie spełnić ilościowe wymagania popytu. Znalazło to odzwierciedlenie w silnych wzrostach cen w latach 20072008 (rys. 2, 3).

Rys. 3. Indeks światowych cen surowców rolnych $(2010=100)$ oraz notowania cen ropy Brent (USD/baryłkę)

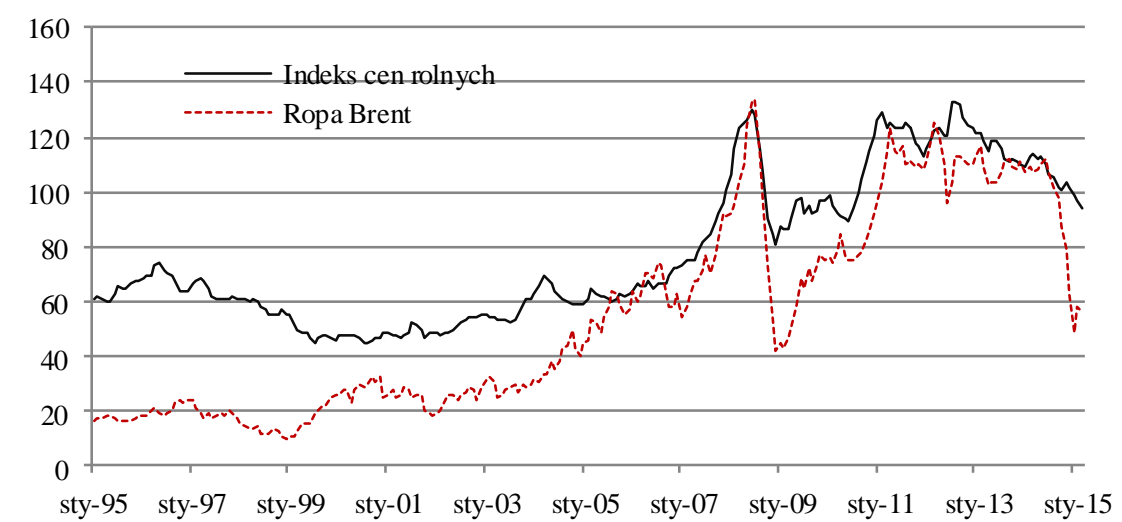

Źródło: opracowanie własne na podstawie danych Banku Światowego.

Wpływ rozwoju rynku biopaliw nie ogranicza się tylko do wcześniej wymienionych rynków surowcowych. Konkurencja o ziemię oraz zależności substytucyjne powodują, że w tym samym czasie mogą wzrastać ceny innych produktów roślinnych, które w niewielkim stopniu (na przykład pszenica) lub w ogóle (między innymi ryż) nie są wykorzystywane do produkcji biopaliw. Dodatkowo efekty kosztowe powodują, że wraz ze wzrostem cen zbóż i roślin oleistych rosną ceny pasz, a co za tym idzie - ceny produktów pochodzenia zwierzęcego.

Empiryczne zależności między cenami ropy a cenami surowców rolnych zobrazowano na dwóch kolejnych rysunkach odnoszących się do miesięcznych notowań, począwszy od 1995 roku. Z rysunku 3 łatwo można wywnioskować, że światowe ceny surowców rolnych w zróżnicowany sposób są powiązane $\mathrm{z}$ cenami ropy. $\mathrm{O}$ ile w pierwszej połowie analizowanego okresu brak wyraźnych związków między cenami, to w drugiej połowie okresu ceny ropy i ceny rolne są już silnej skorelowane. Trzeba mieć świadomość, że indeks stanowi agregat obejmujący również produkty niepowiązane bezpośrednio $\mathrm{z}$ produkcją biopaliw. Zatem w wypadku produktów, takich jak rzepak, soja, cukier czy kukurydza, związki byłyby jeszcze silniejsze.

Na rysunku 4 przedstawiono dwa szeregi czasowe. Pierwszy z nich prezentuje relacje cen indeksu światowych cen surowców rolnych do cen ropy Brent. Można zauważyć dwie zmiany strukturalne w tej relacji: w latach 2000 oraz 2005. Zmiany tych relacji wynikają z relatywnie wysokiego wzrostu cen ropy w stosunku do cen produktów rolnych. Otworzyło to potencjalne (ekonomiczne) możliwości wykorzystania surowców rolnych do produkcji paliw płynnych. 
Rys. 4. Relacje indeksu światowych cen surowców rolnych do cen ropy Brent (dane z rys. 3) oraz współczynniki 12-miesięcznych korelacji ruchomych między ich skorygowanymi sezonowo logarytmicznymi stopami zwrotu

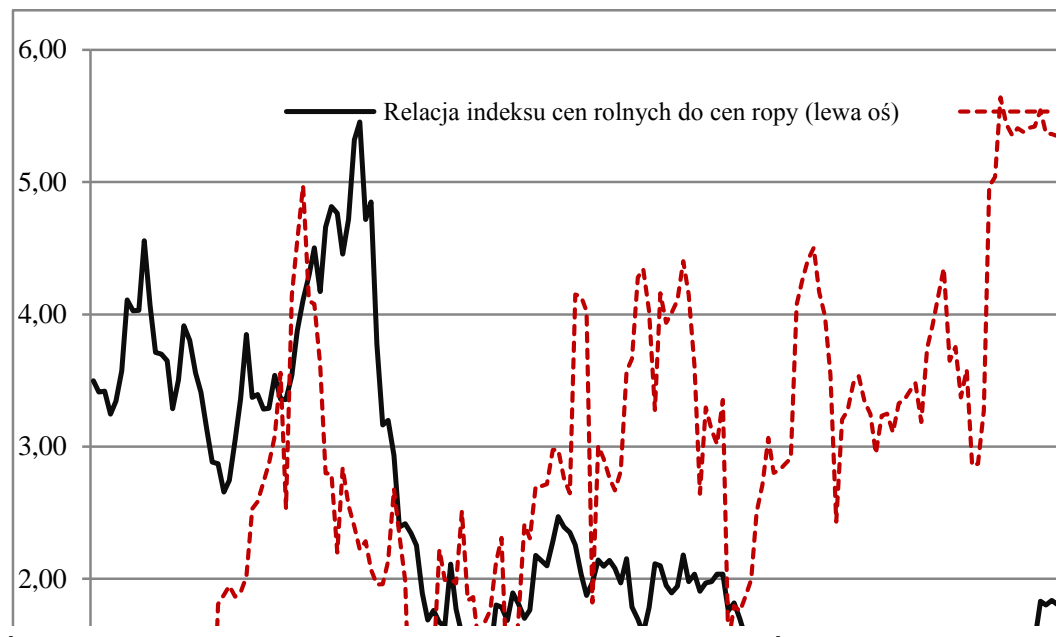

Źródło: obliczenia własne na podstawie danych Banku Światowego.

Drugi szereg czasowy (wyskalowany na prawej osi) przedstawia współczynniki korelacji ruchomej (centrowane) dla okna wynoszącego 12 miesięcy między pierwszymi różnicami logarytmów szeregów czasowych z rysunku 3, które to szeregi dodatkowo skorygowano $\mathrm{z}$ wahań sezonowych. Operowanie pierwszymi różnicami eliminuje w pewnym stopniu wpływ pozornych korelacji, ponieważ wyjściowe szeregi czasowe są niestacjonarne. Wielkości współczynników potwierdzają, że mamy do czynienia z coraz silniejszym powiązaniem w czasie między cenami surowców rolnych a cenami ropy. Można dodać, że podobne wnioski można sformułować, bazując na współczynnikach korelacji obliczonych na poziomach szeregów czasowych.

Warto zaznaczyć, że siła związku, mierzona współczynnikiem korelacji, między cenami ropy a cenami surowców rolnych jest powiązana $\mathrm{z}$ wysokością cen ropy oraz wzajemnej relacji tych cen. Potwierdza to, że wysokie ceny ropy powodują wzrost zainteresowania alternatywnym źródłami energii. Związek między cenami ropy i surowców rolnych w ostatnim roku osłabił się. Można to wiązać ze spadkami cen ropy, obniżeniem opłacalności produkcji biopaliw oraz zapowiedziami obniżenia minimalnych udziałów biopaliw w paliwach wykorzystywanych w transporcie w Unii Europejskiej.

Naturze związków między cenami surowców rolnych a cenami ropy poświęcono wiele badań różniących się między sobą zakresem czasowym i przestrzennym, częstotliwością danych oraz stosowaną metodyką. Przegląd ważniejszych badań w tym zakresie zawiera między innymi praca Serry i Zilbermana ${ }^{14}$. Ogólne wnioski z przeglądu badań zasadniczo sprowadzają się do tych zaprezentowanych w poprzednim akapicie. Siła związków między cenami wrasta w czasie, ale natura tych powiązań jest niejednoznaczna. Testy przyczynowości w sensie Grangera w wypadku większości badań wskazują, że ceny ropy

14 T. Serra, D. Zilberman, Biofuel-related price transmission literature: A review, „Energy Economics" 2013/37, s. 141-151. 
wpływają na ceny kukurydzy, pszenicy, soi czy cukru. Efekt ten jest przenoszony przez ceny bioetanolu i ceny biodiesla.

Co do długookresowej współzależności to wyniki są mniej jednoznaczne, ale w większości badań w tym zakresie wskazuje się na zależności kointegracyjne. Przy czym wskazuje się, że bardziej prawdopodobna jest nieliniowa kointegracja ${ }^{15}$ ze względu na zmieniające się w czasie reżimy uwarunkowane zmianami relacji cenowych, koniunkturą gospodarczą czy też niejednolitym instrumentarium polityki ekonomicznej. Powiązania między cenami rolnych a cenami ropy można rozpatrywać nie tylko na gruncie poziomów cen, ale również $\mathrm{w}$ aspekcie transmisji zmienności między cenami. Badania $w$ tym zakresie również potwierdzają, że po 2005 roku podwyższonej zmienności cen na rynku ropy towarzyszy wyższa zmienność cen surowców rolnych ${ }^{16}$.

\section{BEZPIECZEŃSTWO ŻYWNOŚCIOWE I BEZPIECZEŃSTWO ENERGETYCZNE ŚWIETLE ZMIAN CEN}

W niniejszej części opracowania spróbowano naświetlić związki między bezpieczeństwem energetycznym a bezpieczeństwem żywnościowym w nawiązaniu do produkcji energii opartej na surowcach pochodzenia rolniczego. Aby tego dokonać, należy wyjść od zdefiniowania obydwu tych kategorii, a następnie na tej podstawie dokonać oceny interakcji między nimi.

Międzynarodowa agencja ds. energetyki, w większości skupiająca kraje OECD, określa bezpieczeństwo energetyczne jako niezakłóconą dostępność do źródeł energii po przystępnej cenie. Bezpieczeństwo to może być rozpatrywane $\mathrm{w}$ długiej perspektywie (inwestycje sektorowe zgodne z potrzebami gospodarki i wymaganiami środowiska), jak i krótkiej (zdolność systemu energetycznego do niezwłocznego reagowania na nagłe zmiany równowagi popytu i podaży, w tym cen).

Wiele problemów nastręcza pomiar bezpieczeństwa energetycznego czy uchwycenie za pomocą jednej wielkości liczbowej wielu jego aspektów. W tym celu stosuje się pewne miary agregatowe (indeksy), które pozwalają oszacować bezpieczeństwo energetyczne jako średniej ważonej wskaźników opisujących najważniejsze obszary. Zaletą takiego miernika jest jego skorelowanie $\mathrm{z}$ najważniejszymi wydarzeniami w czasie, które mają odzwierciedlenie w poszczególnych wskaźnikach, oraz możliwość zrozumienia komplementarności między różnymi wymiarami bezpieczeństwa.

Literatura w tym zakresie zwiera wiele propozycji. Przykładowo, Sovacool ${ }^{17}$ wskazuje, że najważniejsze obszary, które powinien obejmować taki indeks, to: dostępność fizyczna, przystępność cenowa, technologia i efektywność, przyjazność dla środowiska oraz kwestie regulacyjne. Jednym $\mathrm{z}$ bardziej znanych indeksów jest międzynarodowy indeks bezpieczeństwa energetycznego (International Index of Energy Security Risk) tworzony przez Instytut Energii XXI Wieku Amerykańskiej Izby Handlowej. Pierwowzorem dla niego był amerykański indeks bezpieczeństwa

\footnotetext{
15 N. Merkusheva, G. Rapsomanikis, Nonlinear cointegration in the food-ethanol-oil system: evidence from smooth threshold vector error correction models, „ESA Working Paper” 2014/14-01, Rome, FAO.

${ }^{16}$ T. Serra, D. Zilberman, J.M. Gil, B.K. Goodwin, Nonlinearities in the U.S. corn-ethanol-oilgasoline price system, „Agricultural Economics” 2011/42, s. 35-45.

${ }^{17}$ B.K. Sovacool, An international assessment of energy security performance, „Ecological Economics" 2013/88, s. 148-158.
} 
energetycznego. Międzynarodowy indeks oparty jest na 29 wskaźnikach obejmujących osiem obszarów ${ }^{18}$ :

1. Globalna podaż (rezerwy i podaż surowców energetycznych);

2. Import surowców energetycznych (bezpieczeństwo bazy surowcowej);

3. Wydatki na energię (narażenia konsumentów na zmiany cen energii);

4. Cena i zmienność rynku (podatność gospodarek narodowych na wahania cen energii);

5. Zużycie energii (pomiar intensywności zużycia);

6. Sektor elektroenergetyczny (niezawodność mocy wytwórczych);

7. Sektor transportowy (efektywności wykorzystania energii w sektorze transportu);

8. Środowisko (nawiązanie międzynarodowych zleceń w zakresie redukcji emisji gazów cieplarnianych).

Poziom tego indeksu dla krajów OECD wzrastał do roku 2010 (z 0,75 do 1,03), obrazując spadek bezpieczeństwa energetycznego, natomiast $w$ ostatnich latach można zaobserwować jego znaczący spadek (do poziomu 0,91 w 2013 roku). Wynika to z wielu czynników, w tym pewien udział ma wzrost wykorzystania odnawialnych źródeł energii opartych na surowcach pochodzenia rolniczego. Wzrastająca krajowa i światowa podaż surowców energetycznych prowadzi do zmniejszenia presji na ceny paliw i energii. Tym samym maleją wydatki na energię, zarówno przedsiębiorstw, jak i gospodarstw domowych. Dodatkowo w wypadku państw importujących ropę następuje zmniejszenie uzależnienia od importu surowców energetycznych. Istotnego znaczenia nabiera również wzrost siły przetargowej importerów surowców energetycznych. Jednakże wiele krajów (a w skali mikro - przedsiębiorstw) importuje surowce stosowane do produkcji tzw. energii odnawialnej (np. do współspalania czy surowce do produkcji biopaliw), co powoduje, że poprawa samowystarczalności energetycznej nie jest aż tak duża. Według szacunków w 2008 roku import biopaliw i surowców do ich wytwarzania w UE stanowił około $40 \%$ ich zużycia $^{19}$.

Pozytywne efekty środowiskowe, które były podstawą polityk zwiększających popyt na surowce rolne do celów energetycznych, nie są już tak oczywiste. Wynika to z tego, że do produkcji surowców rolnych przeznaczanych na cele energetyczne wykorzystuje się mniej przyjazne środowisku technologie (wysokie nawożenie), a rośliny służące do produkcji biopaliw zużywają dużo wody (chyba najważniejsze dobro publiczne, które jest bardzo ograniczone). Wspomniany wcześniej import biopaliw i surowców poprzez ich transport tworzy dodatkową presję na środowisko. Dodatkowo do wyprodukowania energii ze źródeł odnawialnych należy wykorzystać pewną ilość energii ze źródeł konwencjonalnych, co zasadniczo zmniejsza pozytywne efekty w zakresie poprawy bezpieczeństwa energetycznego.

Równie złożonym i podlegającym ewolucji w czasie pojęciem jest bezpieczeństwo żywnościowe ${ }^{20}$. Zgodnie $\mathrm{z}$ definicją Organizacji Narodów Zjednoczonych do spraw

\footnotetext{
${ }^{18}$ Institute for 21 st Century Energy, U.S. Chamber of Commerce, International Energy Security Risk Index Report 2015, Assessing Risk in a Global Energy Market, 2015.

${ }^{19}$ EuropAfrica, (Bio)Fueling Iinjustice? Europe's responsibility to counter climate change without provoking land grabbing and compounding food insecurity in Africa, 2011.

${ }_{20}$ J. Michalczyk, Bezpieczeństwo żywnościowe w obliczu globalizacji, „Ekonomia (Economics)” 18/1 (2012), s. 9-23.
} 
Wyżywienia i Rolnictwa (FAO, Food and Agriculture Organization) ${ }^{21}$ bezpieczeństwo żywnościowe oznacza stan, w którym zagregowana podaż żywności jest wystarczająca do wyżywienia ludności w sposób zapewniający aktywne i zdrowe życie. Bezpieczeństwo żywnościowe można rozpatrywać w krótkim okresie (krótkookresowe wahania podaży i cen) lub w długim (uwzględniając długookresowe trendy w zakresie zmian liczby ludności, obszaru użytków rolnych, technologii produkcji rolnej oraz alternatywnego wykorzystania surowców rolnych). Organizacja FAO definiuje bezpieczeństwo żywnościowe za pomocą kilkudziesięciu wskaźników podzielonych na cztery obszary:

1. Dostępność podaży (dostateczna produkcja i podaż);

2. Dostępność fizyczna i ekonomiczna (infrastruktura, ceny, udział wydatków na żywność, wzrost gospodarczy);

3. Stabilność (uzależnienie od importu, system polityczny, zmienność produkcji i cen);

4. Możliwości wykorzystania (dostępność infrastruktury wodno-sanitarnej, niedożywienie).

Niestety ze względu na niepełne dane nie jest tam wyliczany ani wskaźnik globalny, ani wskaźnik zagregowany dla poszczególnych państw. Próbę budowy takiego wskaźnika - Global Food Security Index - podjęli ekonomiści z The Economist Intelligence Unit, ale dostępny indeks obejmuje dane dopiero od 2012 roku. Wskaźniki dzielone są tam na trzy kategorie: przystępność cenowa, dostępność fizyczna oraz jakość i bezpieczeństwo żywności, gdzie sugerowane wagi to odpowiednio: 40, 44 i 16\% ${ }^{22}$.

Wykorzystanie surowców rolnych pierwszej generacji do produkcji odnawialnych źródeł energii przyczyniło się do obniżenia bezpieczeństwa żywnościowego w dotychczasowej perspektywie $^{23}$. Z teoretycznego punktu widzenia, i w nawiązaniu do obszarów bezpieczeństwa żywnościowego, można wskazać kilka kanałów, którymi się to odbywa. Przede wszystkim wynika to $\mathrm{z}$ obniżenia podaży surowców na cele żywnościowe oraz spadku stanu zapasów. Efekt ten był istotny, ponieważ wymuszony regulacyjnie wysoki przyrost popytu na biopaliwa w wielu krajach przewyższał tempo wzrostu produktywności (plonów), co doprowadziło do spadku wskaźników samowystarczalności ${ }^{24}$. Coraz silniejsze powiązania rynku rolnego $\mathrm{z}$ rynkiem energetycznym doprowadziły do wzrostu cen surowców rolnych w odpowiedzi na wzrost cen ropy, co w konsekwencji znalazło odzwierciedlenie we wzroście cen żywności. Ze wględu na różnorodność czynników trudno jednoznacznie określić wpływ rynku energetycznego na zmiany cen rolno-żywnościowych.

Ceny żywności oraz związane z nimi wydatki na żywność określają bezpieczeństwo żywnościowe w aspekcie dostępności ekonomicznej. Skutki wzrostu cen żywności odczuwają przede wszystkim najbiedniejsze państwa, gdzie udział wydatków na żywność gospodarstw domowych często przekracza 50\% ogółu wydatków. Na negatywne skutki

\footnotetext{
${ }^{21}$ FAO, IFAD, WFP, The State of Food Insecurity in the World 2014. Strengthening the enabling environment for food security and nutrition. FAO, Rome 2014.

${ }^{22}$ GFSI, Global food security index 2014. An annual measure of the state of global food security, The Economist Intelligence Unit Limited 2014.

${ }^{23}$ S. Figiel, M. Hamulczuk, The effects of increase in production of biofuels on world agricultural prices and food security, „European Scientific Journal” 2013/1, s. 10-17.

${ }^{24}$ HLPE, Biofuels and food security. A report by the High Level Panel of Experts on Food Security and Nutrition of the Committee on World Food Security, Rome 2013.
} 
narażone są ponadto kraje, które nie są samowystarczalne żywnościowo - najczęściej są to państwa rozwijające się (głównie w Afryce). Zmniejszenie podaży światowej oraz jednoczesne wzrosty cen spowodowały, że wydatki na żywność w tych krajach znacząco wzrosły, co potwierdzają ogólnodostępne dane. Indeks cen żywności FAO dla państw rozwijających się wzrósł w latach 2005-2014 o 17\%, podczas gdy w analogicznym okresie ceny żywności w krajach rozwiniętych wzrosły jedynie o 1\% (w stosunku do inflacji ogółem). Zatem problem bezpieczeństwa żywnościowego w kontekście produkcji biopaliw jest problemem krajów rozwijających się.

Warto wspomnieć o innych konsekwencjach. Wzrost popytu na ziemię do produkcji biopaliw spowodował nasilenie tzw. zjawiska wykupu ziemi w krajach rozwijających się przez międzynarodowe korporacje na cele energetyczne (land grabbing) ${ }^{25}$. Nie tylko zmniejsza to dostępne zasoby ziemi na cale żywnościowe (i tak niewystarczające), ale dodatkowo narusza równowagę środowiskową i społeczną. Efekty wzrostu cen żywności uwidoczniły się po roku 2007, doprowadzając do niepokojów społecznych, które zapoczątkowały tzw. Arabską Wiosnę. Liczba i siła tych niepokojów jest dodatnio skorelowana ze wzrostami cen światowych ${ }^{26}$.

Można sądzić, że w przyszłości możliwości pogodzenia bezpieczeństwa żywnościowego i energetycznego będą zależały ciągle od kształtu polityki energetycznej oraz relacji cenowych. Wydaje się, że w kontekście obserwowanego spadku cen ropy oraz negatywnych konsekwencji, jakie były obserwowane w ostatnich latach, trudno będzie ją utrzymywać. Jednym z przejawów zmian są ostatnie decyzje Komisji Europejskiej o obniżeniu obowiązkowych limitów domieszek biokomponentów, które zmierzają też do większego powiazania produkcji z czynnikami rynkowymi. Wskazane wcześniej czynniki oraz wzrost produkcji rolnej i związana $\mathrm{z}$ tym odbudowa stanu zapasów żywności $\mathrm{w}$ świecie mogą sprawiać, że negatywne konsekwencje produkcji biopaliw dla bezpieczeństwa żywnościowego będą coraz mniejsze.

\section{PODSUMOWANIE}

Przeprowadzone badania wskazują, że bezpieczeństwo żywnościowe i bezpieczeństwo energetyczne są ze sobą powiązane. Poprawie bezpieczeństwa energetycznego towarzyszy obniżenie bezpieczeństwa żywnościowego. Głównym kanałem oddziaływania są ceny, a dokładnie - relacje miedzy cenami ropy a cenami surowców rolnych wykorzystywanych do celów produkcji energii odnawialnej. Siła powiązań cenowych znacząco wzrosła w ostatnich latach na skutek aktywnej polityki państw rozwiniętych promujących wzrost konsumpcji biopaliw pierwszej generacji.

W największym stopniu spadek bezpieczeństwa żywnościowego dotknął kraje rozwijające się oraz importerów żywności. Mieliśmy do czynienia z asymetrią korzyści i strat na arenie międzynarodowej: beneficjentami okazały się kraje rozwinięte, koszty zaś poniosły kraje rozwijające się. Analizy leżące u podstaw projektowania instrumentów polityki biopaliwowej nie doszacowały ich rzeczywistego wpływu na ceny żywności oraz możliwości destabilizacji politycznej krajów rozwijających się. Wydaje się, że ostatnie propozycje obniżenia limitów zużycia biopaliw w paliwach płynnych w UE idą w dobrym kierunku. Tym samym bliższe jest to zasadzie mówiącej, że polityka energetyczna

\footnotetext{
${ }^{25}$ Ibidem.

${ }^{26}$ M. Lagi, K.Z. Bertrand, Y. Bar-Yam, The Food Crises and Political Instability in North Africa and the Middle East, NECSI, Cambridge 2011.
} 
(biopaliwowa) nie powinna stanowić zagrożenia dla produkcji żywności, dostępności do wody czy porządku społecznego.

\section{LITERATURA}

[1] Baffes J., Dennis A., Long-term drivers of food prices, „Policy Research Working Paper" 2013/6455, World Bank, Washington, D.C..

[2] Cheng I.-W., Xiong W., The Financialization of Commodity Markets, „NBR Working Paper" 2013/19642.

[3] de Gorter H., Drabik D., Just D.R., Biofuel Policies and Food Grain Commodity Prices 2006-2012: All Boom and No Bust? „AgBioForum” 16/1 (2013), s. 1-13.

[4] EuropAfrica, (Bio)Fueling Injustice? Europe's responsibility to counter climate change without provoking land grabbing and compounding food insecurity in Africa, 2011.

[5] FAO, IFAD, WFP, The State of Food Insecurity in the World 2014. Strengthening the enabling environment for food security and nutrition, FAO, Rome 2014.

[6] Figiel S., Hamulczuk M., The effects of increase in production of biofuels on world agricultural prices and food security, „European Scientific Journal” 2013/1, s. 7-17.

[7] GFSI 2014: Global food security index 2014. An annual measure of the state of global food security, ,The Economist Intelligence Unit Limited” 2014.

[8] Hamulczuk M., Polityka biopaliwowa a ceny surowców rolnych - wybrane problemy, „Roczniki Naukowe Stowarzyszenia Ekonomistów Rolnictwa i Agrobiznesu" 16/2 (2014), s. 82-87.

[9] Headey D., Fan S., How Did It Happen? How Has It Hurt? and How Can We Prevent the Next One?, „Research Monographs” 2010/165, IFPRI.

[10] HLPE. Biofuels and food security. A report by the High Level Panel of Experts on Food Security and Nutrition of the Committee on World Food Security, Rome 2013.

[11] Institute for 21st Century Energy, U.S. Chamber of Commerce, International Energy Security Risk Index Report 2015, Assessing Risk in a Global Energy Market, 2015, www.energyxxi.org.

[12]Lagi M., Bertrand K.Z., Bar-Yam Y., The Food Crises and Political Instability in North Africa and the Middle East, NECSI, Cambridge, 2011.

[13] McPhail L.L., Babcock B.A., Impact of US biofuel policy on US corn and gasoline price variability, „Energy” 37/1 (2012), s. 505-513.

[14] Merkusheva N., Rapsomanikis G., Nonlinear cointegration in the foodethanol-oil system: evidence from smooth threshold vector error correction models, „ESA Working Paper” 2014/14-01, FAO, Rome.

[15] Michalczyk J., Bezpieczeństwo żywnościowe w obliczu globalizacji, „Ekonomia (Economics)” 18/1 (2012), s. 9-23

[16] Nazlioglu S., Soytas U., Oil price, agricultural commodity prices and the dollar: A panel cointegration and causality analysis, „Energy Economics” 2012/34, s. 1098-1104.

[17] Robles M., Torero M., von Braun J., When speculation matters, „Issue Brief” 2009/57, International Food Policy Research Institute, Washington. 
[18] Sovacool B.K., An international assessment of energy security performance, „Ecological Economics” 2013/88, s. 148-158.

[19] Serra T., Zilberman D., Biofuel-related price transmission literature: $a$ review. „Energy Economics” 2013/37, s. 141-151.

[20] Serra T., Zilberman D., Gil J.M., Goodwin B.K., Nonlinearities in the U.S. corn-ethanoloil-gasoline price system, „Agricultural Economics” 2011/42, s. $35-45$.

[21] Sharma R., Food Export Restrictions: Review of the 2007-2010 Experience and Considerations for Disciplining Restrictive Measures, "FAO Commodity and Trade Policy Research Working Paper" 2011/32.

[22] Timmer C.P., Causes of High Food Prices, „ADB Economics Working Papers" 2008/128.

[23] Troester B., The determinants of the recent food price surges - a basic supply and demand model, „Berlin Working Papers on Money, Finance, Trade and Development" 2012/6.

[24] Trostle R., Global Agricultural Supply and Demand: Factors Contributing to the Recent Increase in Food Commodity Prices, WRS-0801, ERS-USDA 2008.

[25] Trostle R., Marti D., Rosen S., Westcott P., Why Have Food Commodity Prices Risen Again?, WRS-1103, ERS-USDA 2011.

[26] Tyner W.E., Taheripour F., Hurt Ch., Potential Impacts of a Partial Waiver of the Ethanol Blending Rules, Farm Foundation, Oak Brook 2012, s. 1-13.

[27] von Lampe M., Kavallari A., Bartelings H., v. Meijl H., Banse M., IlicicKomorowska J., Junker F., van Tongeren F., Fertiliser and Biofuel Policies in the Global Agricultural Supply Chain: Implications for Agricultural Markets and Farm Incomes, „OECD Food, Agriculture and Fisheries Papers" 2014/69.

[28] Will M.G., Prehn S., Pies I., Glauben T., Is financial speculation with agricultural commodities harmful or helpful? A literature review of current empirical research, „Diskussionspapier” 2012/26, des Lehrstuhls für Wirtschaftsethik an der Martin-Luther-Universität Halle-Wittenberg, Halle.

[29] Wright B.D., Global Biofuels: Key to the Puzzle of Grain Behavior, „Journal of Economic Perspectives" 28/1 (2014), s. 73-98.

\section{ENERGY PRICES VS AGRI-FOOD PRICES - ENERGY SECURITY AND} FOOD SECURITY

The last years are characterized by a significant increase of agri-food prices, accompanied by a growth of their volatility. An increase of agricultural markets linkages with energy market is indicated a major factor underling this state. This is the result of increasingly widespread use of agricultural raw materials for the production of renewable energy, which is justified, inter alia, by environmental and energy security concerns.

In this context, the first objective of the research was to assess the relationship between energy prices and agri-food prices. Against this background, the relationship between energy security and food security was considered. The study focused on a global perspective.

The results confirm the increase of the linkage between energy prices and the prices of agricultural commodities and food. This is expressed inter alia by an increase in the correlation between the price index of agricultural commodity prices and the price of Brent 
crude oil as well as a visible correlation of their volatility. The increase in price relationships resulted from many causes, including an active policy of developed countries aimed to promote the production and consumption of biofuels.

The effect of the increase in food prices was decrease of food security, especially in developing countries, accompanied by social unrest. At the same time in countries producing biofuel the energy security has improved. However, it seems that with the rebuilding stocks of food, the reduction in oil prices and stabilization of the agricultural sector involvement adverse consequences for food security will become lower.

Keywords: agro-food prices, energy prices, energy security, food security.

DOI:10.7862/rz.2016.hss.3

Przesłano do redakcji: czerwiec 2015

Przyjęto do druku: styczeń 2016 